\title{
CREATIVEPRENEUR ON SEKOPER PROJECT : WOMEN EMPOWERMENT PROGRAM FOR ECONOMIC EMANCIPATION
}

\author{
Eka Srirahayu Ariestiningsih ${ }^{1}$, Genoveva ${ }^{2}$, Dwi Faqihatus Syarifah Has ${ }^{3}$ \\ ${ }^{1}$ Health Faculty,Science of Nutrition Study Program,Muhammadiyah Gresik \\ University, ${ }^{2}$ Business Faculty, Management Study Program,President University, \\ ${ }^{3}$ Health Faculty,Science of Nutrition Study Program,Muhammadiyah Gresik University, \\ Email : eka.ariesty@umg.ac.id, genoveva@president.ac.id, \\ dwi_syarifah@umg.ac.id
}

\begin{abstract}
The aim of this research is to find out how to improve the quality of life of SEKOPER members to become creativepreneur, which is a form of women's empowerment program for economic emancipation. This is program for gender equality and justice, developing and strengthening women's knowledge and learn poverty alleviation as the social protection programs, which is organized by Gresik Regency Government because many women dropped out of school and un-productive. According to data from the Central Statistics Bureau, the female unemployment in 2019 it increased significantly to $5.92 \%$. To achieve this goal, researchers used a qualitative method, with primary and secondary sources as data collection instruments, namely observation, in-depth interviews, and using the Participatory Rural Appraisal approach. Based on the analyzed data, the research findings that SEKOPER members have succeeded in becoming creativepreneur with : 1) Facilities and policy from Head of village as the Regional Government, 2) Coaching from UMG and President University as a higher education institutions that provides innovative healthy food and how to market the products and 3) Sponsorship by Combined Cycle Power Plant (PJB) as their CSR program. The success of developing an innovative healthy food business, it will improve the economy of the family and the region, which is form of economic emancipation.
\end{abstract}

Keywords : SEKOPER, Women Empowerment, Economic Emancipation

\begin{abstract}
Abstrak
Tujuan dari penelitian ini adalah untuk mengetahui bagaimana meningkatkan kualitas hidup anggota SEKOPER agar mampu menjadi creativepreneur, yaitu wujud dari program pemberdayaan perempuan dibidang emansipasi ekonomi. Hal ini merupakan program kesetaraan dan keadilan gender yang bertujuan untuk pengembangan dan penguatan pengetahuan perempuan sebagai pusat pembelajaran terkait pengentasan kemiskinan melalui pemantauan program perlindungan sosial,yang diselenggarakan oleh Pemerintah Kabupaten Gresik disebabkan banyaknya perempuan putus sekolah dan tidak produktif. Menurut data Badan Pusat Statistik (BPS) Kabupaten Gresik, tingkat pengangguran perempuan pada 2019 meningkat signifikan sebesar 5,92\%.
\end{abstract}


Untuk mencapai tujuan tersebut, peneliti menggunakan metodologi kualitatif, dengan sumber primer dan sekunder sebagai instrumen pengumpulan data yaitu dengan metode observasi, wawancara mendalam dan menggunakan pendekatan Participatory Rural Appraisal (PRA). Berdasarkan analisis data, temuan penelitian menunjukkan bahwa anggota SEKOPER berhasil menjadi Creativepreneur dengan (1) fasilitas dan kebijakan Kepala Desa selaku Pemerintah Daerah, (2) pendampingan dari Universitas Muhammadiyah Gresik dan President University sebagai institusi pendidikan tinggi yang memberikan pelatihan dan keterampilan menciptakan makanan sehat yang inovatif dan cara memasarkan produk, serta (3) didukung oleh Perusahaan Listrik PT Pembangkit Jawa Bali (PJB) sebagai Corporate Social Responsibility (CSR). Dengan keberhasilan mengembangkan bisnis makanan sehat yang inovatif, maka akan membantu meningkatkan ekonomi keluarga dan wilayahnya. Keberhasilan tersebut merupakan salah satu bentuk emansipasi ekonomi.

Kata Kunci : Sekoper, Pemberdayaan Perempuan, Emansipasi Ekonomi

\section{A. INTRODUCTION}

The development of a gender responsive environment is needed to obtain an even welfare of life between men and women. In Indonesia women dropp out of school, continues to increase, from 2018-2020 there was a total increase of $57.9 \%$, the annual average was $19.3 \%$. Indonesian cultural values provide a place for women as wife and mom only who are limited to domestic activities to limit women's movement. In 2019 data number of school dropouts in the East Java Province is 1.411 unployed women, was in 2nd place after West Java Province. As a result, many Indonesian women still experience a low quality of life, especially in villages one of which is Kramatinggil Village(Lestari, 2017). According to data from the Central Statistics Bureau, the female unemployment rate in 2017 was 5.06\%; 2018 was $4.48 \%$ and in 2019 it increased significantly to $5.92 \%$.(Mu'alifah, 2019). The high number of women dropp out of school and have no working has caused the Gresik Regency Government to take steps in efforts to mainstream gender and equality, partnership with the NGO KAPAL Women Institute, KPS2K, East Java, namely organizing the Women's School Program (SEKOPER)' which is part of the Gender Watch Program related to improving the quality of life of poor women through strengthening the capacity of women's leadership and monitoring of social protection programs. One of the aim of the SEKOPER program is to develop and strengthening women's knowledge houses as learning centers in communities related to poverty reduction through monitoring social protection programs through women's empowerment(Din KBPP dan PA Kab Gresik, 2019)

Referring to previous research(Eka SR dan Dwi FSH, 2020)about the factors that influence the empowerment of posyandu cadresbecome an intrapreneur through BIMA $\mathrm{X}$ product innovation based on creativepreneur, the result study that human resources are the most influential factor in the successful empowerment of posyandu cadres. 
Based on this research, SEKOPER members as human resources are involved in this research, with the hope that the empowerment of SEKOPER members will succeed in becoming creativepreneurs.

From the description above, the aim of this research is to find out how to improve the quality of life of SEKOPER members to become creativepreneur, which is a form of women's empowerment program for economic emancipation. Formulation of the problem in this research is : (1) How the leadership of the head village in solving the problems of dropping school and unemployment womens; (2) How the SEKOPER program educate and empower of dropping school and unemployment women; (3) Wheather the SEKOPER program is capable of realizing economic emancipation; (4) How Muhammadiyah Gresik University, Gresik Regency Government and Combined Cycle Power Plant (PJB) as CSR program supervise and control activitiesdeveloping an innovative healthy food business.

\section{B. LITERATURE REVIEW}

1. Women School / Sekolah Perempuan (SEKOPER)

This program is forum for village women to exchange knowledge and experiences, identify the need and interest of women to improve their quality of life. Sharring knowledge dan experience in SEKOPER related to women's practical needs: (1) increase in family income, culinary skills, Culinary business, Information Technology, (2) justice and gender equality, (3) parenting, (4) nutrition (production and consumption a healthy food), (5) sanitation andaclean and healthy lifestyle; (6) reproductive rights of women, (7) family health, (8) in English language, public speaking, (9) women's leadership, and strategic needs: (1) knowledge of human rights, child, women, majority group, minority group, women as citizens, (2) development planning in local areas and national which affects the lives of women. (3) global economic system and impact on rural women (Sutopo, 2016)

2. Women Empowerment

Rural women are key agents for achieving the transformational economic, environmental and social changes required for sustainable development. But limited access to credit, health care and education are among the many challenges they face, which are further aggravated by the global food and economic crises and climate change. Empowering them is key not only to the well-being of individuals, families and rural communities, but also to overall economic productivity. (UN Women, 2020)

Buyeh Reserch's concluded that unless women are empowered and gender equality is achieved so that women can play their role in economic, social, political, and environmental areas, the country will not achieve sustainable development with the recognition of only men's participation in all these areas. 
The fact that women constitute half the entire population of the country makes empowering them to be an active part of all development initiatives in the country a compelling circumstance.(Buyeh, 2016)

From the results of the study above that empowerment of women is inherent in the conceptual relationship between empowerment and individual or female community groups, so that the concept of empowerment gives a role to women. so that they have the ability and empowerment to determine their life choices to make them better and more useful.

3. Economic emancipation with forming the SEKOPER member's become Creativepreneur

(Bujor A. \& Avasilcai S., 2016)From the results of the study, concluded that creativity is something: new, innovative, original, and unique. Most of the research defining creative is to find something new, but there are some who argue that it does not have to be new. Whether a decision is new or not, one must definitely be innovative, give an original touch, and, ultimately, must have a unique character.

Throsby, 2011 as quoted by (Klerk, 2014), said that creative entrepreneurs are business executives who operate in the economic sector of the creative industry, have distinctive characteristics that influence the people around them because of the nature of the creative industry, their position in society, and their relationship with people in their business operations..

(Genoveva C. \& Kartawaria FN, 2020) Result : Respondents who already have education in the business field would rather contribute to raising the business in more modern ways, such as improving management system selling online and providing better facilities for customer satisfaction .

According to study above the SEKOPER member's given education, training, skills to make innovative healthy food and how the marketing system is to become a business. From the businesses built by SEKOPER member's will realize economic emancipation.

\section{METHODE}

\section{Research Methode}

This researchers used a qualitative method, the aim of this research is to find out how to improve the quality of life of SEKOPER members to become creativepreneur, which is a form of women's empowerment program for economic emancipation. The research samples were the village head, coordinator SEKOPER and 33 women as SEKOPER members Data collection instruments, with primary and secondary sources namely observation, in-depth interviews, and using the Participatory Rural Appraisal (PRA) approach. PRAin (Adimihardja, 2003)is a 
technique that allows people to participate in making concrete actions, supervision, and evaluation of policies that affect their lives, in (Rahadi, 2018).

\section{Research Model}

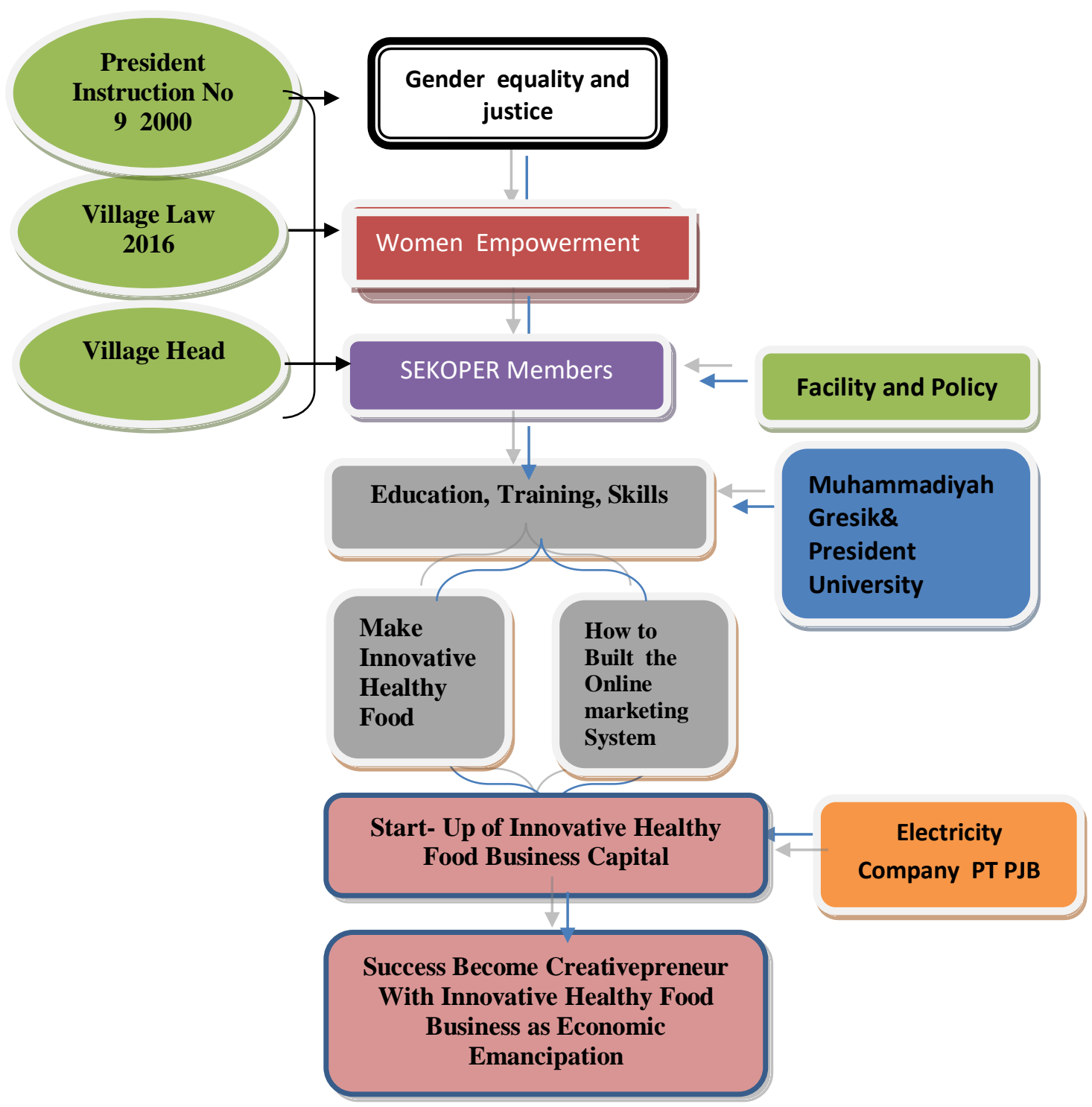

Picture 1 : Research Model 


\section{RESULT And DISCUSSION}

\section{Obervation Result}

a. Village Head Leadership

The leadership of the Kramatinggil Village Head isInovatif-Progresifbe evidencedby the policy of implementing Village Community Empowerment(Mustakim, 2015) isimplementing the SEKOPER programinvolving poor women in the program, to obtain sufficient education, training and skillsto improve their quality of life.

This study is similar to, research(Sudderth, 2020), Programs and policies that handles gender violence in poor rural areas in Nicaragua and developing countries face a number of challenges: high levels of intimate partner violence, low reporting rates, cultural restrictions on women's work, lack of education and adequate health care, In some regions, there are no special services for victims of gender violence. As a result, dealing with intimate partner violence in rural areas in developing countries is empowering rural women economically and socially. Which is one of the program's efforts to empower rural women and the implications for creating safe spaces for victims of violence.

Likewise conducted by the Head of Kramatinggil Village, to protect women from gender violence and poverty, implementing the SEKOPER program, which is a women's empowerment program that aims to improve the quality of life of women, so they can live independently

b. The success of the Women's School Program (SEKOPER)

Amount of SEKOPER members is 1,258 (one thousand two hundred and fifty eight) people are on 7 (seven) sub-districts of Gresik Regency(Din KBPP dan PA Kab Gresik, 2019; Din KBPP dan PA Kab Gresik, 2019). The main program ofGender Watchable to prove that there is an increase in the capacity of rural women to become village cadres, and has accelerated the opening of access to the fulfillment of basic rights for women. According to Adi Yumanto in (setiono, 2018).

Through SEKOPER, the Gresik district government received awards, each of which was a National awardInnovative Governance Award/IGA 2017 and the 2018 Autonomous Award(Din KBPP dan PA Kab Gresik, 2019) 

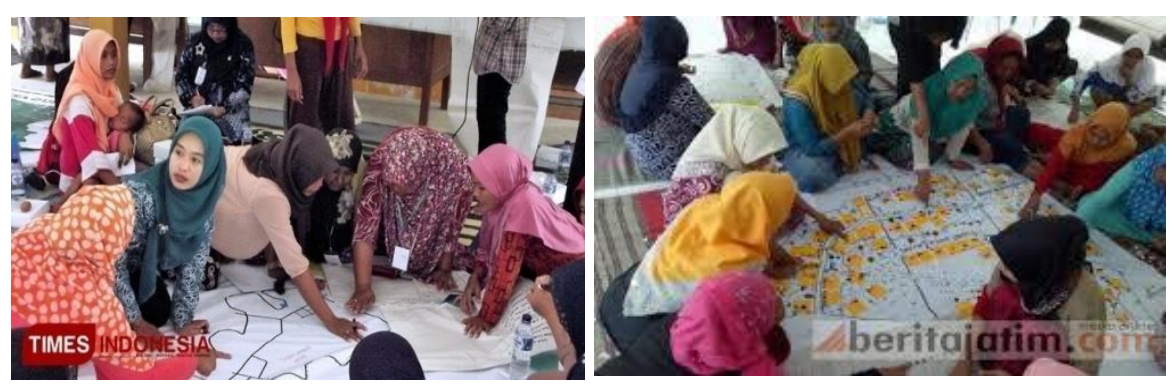

Picture 2 : Activities SEKOPER Kramatinggil Village

The success of the SEKOPER program which forms women's creativepreneur aimed at increasing economic emancipationis a synergy of strengths from (1) Higher Education realm (Muhammadiyah Gresik University) (2) Business realm (PLTGU PT PJB) and (3) Government (Kramatinggil Village Head and Family Planning Agency, Women's Empowerment and Child Protection)

In this research, intervention carried out to SEKOPER members focus more on processingan innovative healthy foodwhich iscreative atau inovatif product mix of Moringa Oleifera and how to built the online marketing System, like Instagram, Whatsapp Grup, and join the Gresik online merchant community.

\section{Interview Result}

To achieve the objectives of this study, the researchers conducted interviews with several source

\section{Researcher :}

How do you support the program which is one of the replications of the SEKOPER programin Gresik Regency as an effort to alleviate poverty.

\section{Village Head:}

SEKOPER members at Kramatinggil village,are women who get assistance from the government, such as: a widow (divorced, domestic violence or her husband died), and women dropped out of school and have no income.

SEKOPER Program Kramatinggil village, is one that succeed because of the many stepsand activities which is conductedincluding the Productive Village, sponsored by PLTGU PT BJB, where the hamlets in Kramatinggil Village are named according to the advantages of each hamlet, for example: Medicinal Plants for Family, Vegetable, Fruit (Orange) and Moringa hamlets, the funds use ADD and PLTGU PT PJB 


\section{Researcher :}

How is the role of the village head in managing SEKOPER, and its benefits

\section{SEKOPER Program Members :}

The Village Head provides ADD funds for the implementation of the program.Village funds used for Women's Empowerment activities use the 2019 Village Fund Budget:258.633.000,00 IDR.

The benefit of SEKOPER is to provide education aboutgender equality, empowering women and voicing women's rightsand provide useful skills to eradicate poverty and improve welfare

From the observation of data either through the website and leaflets or posters about the SEKOPER program issued by the KBPP\& PA Gresik Regency Government and interviewresultproven that SEKOPER is a women's empowerment program capable of improving the quality of life of women,educate, train to provide skills to create creativity and innovation and be ready to become a Creativepreneur. Some of SEKOPER members have also succeeded in marketing healthy and innovative food products as a form of economic emancipation.

\section{Discussion}

a. Creativepreneuron SEKOPER Projectgave birth to the owner of the Healthy and innovation Food Business

SEKOPER members are village women who are trained, educated and given skills to become creativepreneurthat will be business dealing as wellable to develop the economy of the family and the region

The results of this study are similar previous studies conducted byDjayagunawan in Genoveva : Gender has an influence on entrepreneurial desires, entrepreneurial women have better performance than male. Among some researchers who explain groups that have family businesses have higher entrepreneurial intention than those who do not have a family business (Genoveva, 2019; Chrisman, Chua and Steier, 2003; Nandamuri and Gowtami, 2013).(Genoveva and Filbertha Nathania Kartawaria, 2020; Genoveva C. \& Kartawaria FN, 2020)

Such as Genoveva research result, that gender affects entrepreneurial desire. So it is very appropriate if SEKOPER provides education, skills training and forms creativepreneur to women who are SEKOPER members, because women's performance is better.By producing creative and innovative products, SEKOPER members will operate in the creative industry economic sector with products healthy and innovation food.

Furthermore(Anderson Rei Galvao et.all, 2020) Mentoring entrepreneurship in a rural territory: to understand the importance of an entrepreneurship program 
for a rural territory. The results show that the EMER-n program, by involving local actors (higher education institutions, business associations and local development associations), allowed the creation of a network that led to an entrepreneurial ecosystem in a rural territory.

Referring to the results of the research which explains the importance of mentoring rural communities in running a businessand forming rural business groups through the programEmpreendedorismo em meio rural norte (EMERn) as Entrepreurship in rural nort known in the Portuguese Country as the program it was designed forprovide assistance to entrepreneurs who will develop their business.On EMERn programacademics, business people and business developers are the most effective.

Likewise, SEKOPER Program to train SEKOPER members become a creativepreneur supported by three institutions that is Muhammadiyah Gresik University, Gresik Regional Government andGresik Combined Cycle Power Plant (PLTGU) PT BJB. SEKOPER formed a villagewoman CreativepreneurthroughCoaching from Muhammadiyah Gresik University as a higher education institution that provides innovative healthy food and how to market the products.

Muhammadiyah Gresik University provides training to SEKOPER members in making healthy and innovative foods using moringa.This food is healthy and innovative, highly nutritious because it uses moringa as an additional raw material for contemporary food favored by millennials, namely moringa's nuggets and Moringa's stick. In this coaching using the drill method, which is to provide repeated skills training and invite them to practice processing the food directly and create an Instagram and WAG accountto sell their products online, until they are independently.

For fundingsupported by PLTGU PT Pembangkit Jawa Bali (PJB) as their Corporate Social Responsibility (CSR) program and the government.

The SEKOPER members already have a healthy and innovation food business (nuggets and sticks made from moringa) which are marketed online via Instagram, Whatsapps Group and in the Gresik online merchant community.

\section{b. Women Empowerment Program For Economic Emancipation}

Economic empowerment is central to women's ability to overcome poverty, cope with shocks and improve their well-being. When women realize their economic goals, whether it is growing a business, improving their home or investing in training or education, they are more resilient and able to provide for themselves and their families(A Global Comunities Patner, 2020). conformable with(Sullaida, Nurmala and Chairil Ahyar, 2018) that Empowering women to boost the economy with creative use The Triple Helix Model ia rated effective due 
to building that will strengthen the economy. With the creative industry development model, it will bring the creative industries towards the achievement of the creative industry goals. As well as Buyeh Reserch's that village women are key agents for achieving the transformational economic, environmental and social changes necessary for sustainable development. Empowering women is key not only to the well-being of individuals, families and rural communities, but also to overall economic productivity.If women are empowered and gender equality is achieved, women can play a role in the economic, social, political and environmental fields. The fact is women make up half of the country's population. women's empowerment is an active part of all state development initiative. Sustainable development will not be successful if it is only implemented by men

According with the research results above SEKOPER are women empowerment model. The aim of SEKOPER program is implementing gender mainstreaming in local government development policies and programs especially in gender responsive planning and budgeting to the rural level.

A'Model of women empowerment on SEKOPER program for this economic independence are the same as Triple Helix Models which is synergy of strength (1) Educational Institutiosn; (2) Bussiness Groups and ; (3) Government. SEKOPER has succeeded in forming a women creativepreneur that aims to improved economic emancipationaccompanied by Muhammadiyah Gresik University, Gresik Region Government and PLTGU PT PJB as Corporate Social Responsibility. From the result research (Rahadi, 2018) The actors involved in the ecosystem in industrial development are not limited to the Triple Helix Models, namely intellectual, government and business, but it must broader and involve the creative coummunity and consumer community for creative product. Furthermore (Rahadi, 2018) have an oponion, thatit needed Quad Helix Models of colaboration and linking networks, namely intellectual, government and business and Community. On picture 3 described Quad Helix Models in developing creativepreneur coummunity for economiv emancipation 
Volume : 6 Nomor : 1 Maret 2021

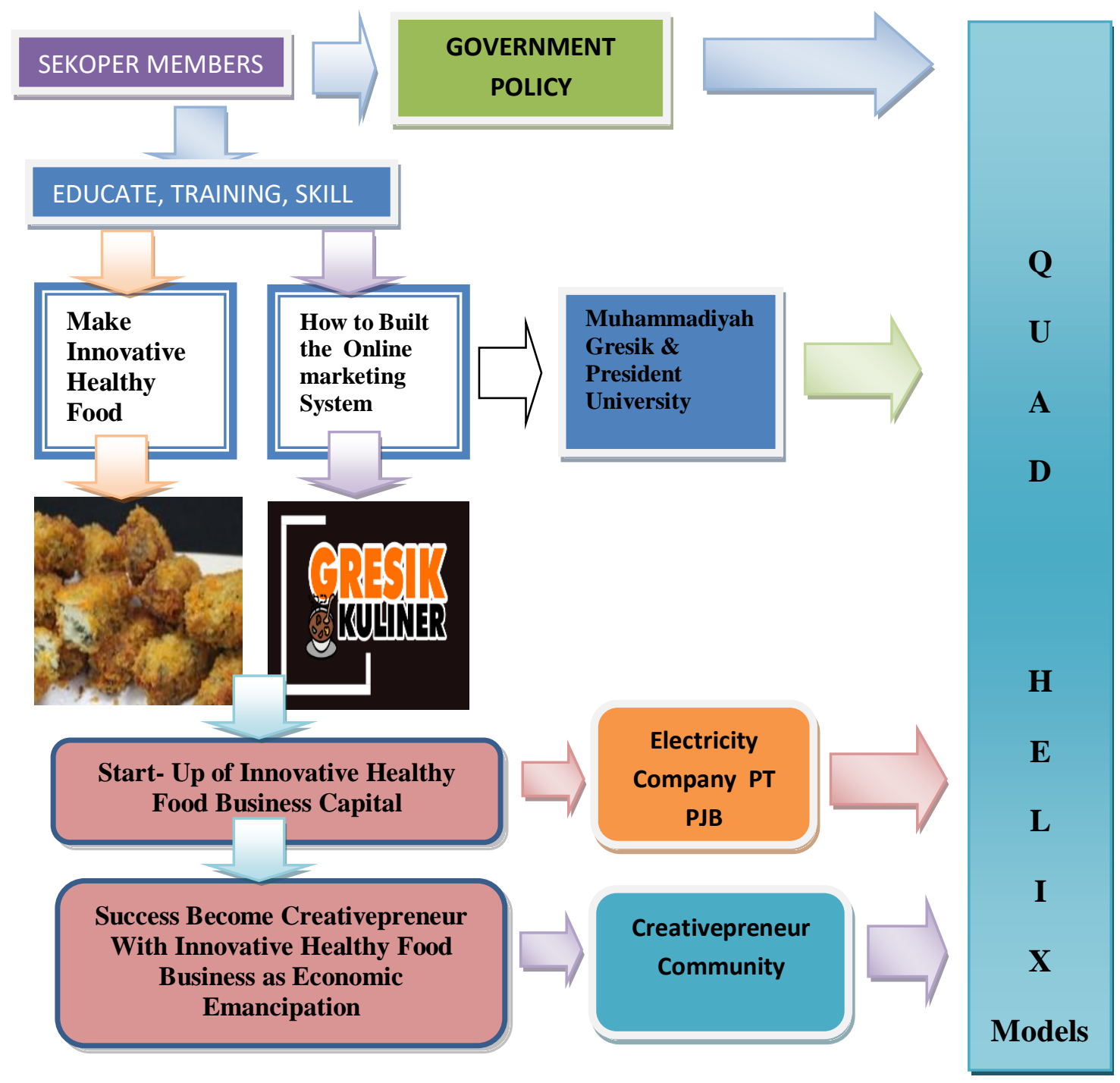

\section{CONCLUSIONS AND RECOMMENDATION}

\section{a. Conclusions}

Conclusion fron the discription above is :

1) The Head of Kramatinggil Village has an Innovative-Progressive leadership type, makes policies and provides facilities in the SEKOPER program which is an empowerment for poor women who drop out of school and are unemployed. SEKOPER members are given education, training and skills in healthy and innovation food processing. Which is the capital of creativepreneur to increase family income and to improve regional economy.

2) $30 \%$ of the SEKOPER members, have successfully developed a business of healthy and innovatif food namely nuggets and stick with local food ingredients, it is Moringa and marketed online they are joined the Gresik online merchant community. 


\section{Volume : 6 Nomor : 1 Maret 2021}

3) Success of SEKOPER program used women empowerment model which strengthens synergy of three companion pillars is Muhammadiyah Gresik University, Region Government and PLTGU PT PJB as Corporate Social Responsibility.

\section{b. Recomendation}

According to the conslusion of this study, then recommendation given is :

1) University of Muhammadiyah Gresik and the Head of Kramatinggil Village (representing the Gresik Regional Government), as well as PLTGU PT PJB improve mentoring, control and evaluate SEKOPER program activities and improve the competence of SEKOPER members

2) Finding additional capital for SEKOPER members who have become creativepreneurs by cooperated with banks to make their businesses more advanced until they become truly independent

3) Provide recommendations to the Gresik Regional Government, to give training and skills in healthy and innovative food processing with local food ingredients to all SEKOPER members in the Gresik Regency, so that economic emancipation can be realized

\section{Bibliography}

A Global Comunities Patner. (2020, May 20). Women's Empowerment Can Change the World. Retrieved from A Global Comunities Patner: https://www.pciglobal.org/empoweringwomen/\#: :text=PCI\%E2\%80\%99s\%20Women\%20Empowered\%20\%28WE\%29\%20progra m\%20focuses\%20on\%20increasing,their\%20financial\%20goals\%20and\%20overcome\%20p ersistent\%2C\%20gender-based\%20barriers.

Adimihardja, K. (2003). Participatory Research Appraisal : Dalam Pelaksanaan Pengabdian Kepada Masyarakat. Bandung: Humaniora Utama Press.

Amin K dan Kadar. (2016). Pengaruh Pemebrdayaan Perempuan Dan peningkatan Ekonomi keluaraga. Buana Gender LP2M IAIN Surakarta, 45-54.

Anderson Rei Galvao et.all. (2020). Mentoring Entrepreuarship In A Rural Territory. Journal Of Rural Studies, 314-324.

Bujor A. \& Avasilcai S. (2016). The Creative Entrepreneur : A Framework Of Analysis. Procedia : Social and Behavioral Sciences, 21-28.

Buyeh, E. (2016). The role of empowering women and achieving gender equality to the sustainable development of Ethiopia. Pasific Science Review B : Humanities And Social Sciences, 37-42.

Din KBPP dan PA Kab Gresik. (2019, Agust 3). Sekolah Perempuan. Kabupaten Gresik, Jawa Timur, Indonesia. 


\section{Volume : 6 Nomor : 1 Maret 2021}

Eka SR dan Dwi FSH. (2020). Analisis Faktor Keberhasilan Pemberdayaan Kader Posyandu Sebagai Intrapreneur Melalui Produk BIMA X Berbasis Creative Entrepreneur. FIRM Journal Of Management Studies, 78-98.

Genoveva and Filbertha Nathania Kartawaria. (2020). Asian and African Business Students: A Comparative Analysis. International Journal of Economics and Business Administration, 109-123.

Genoveva C. \& Kartawaria FN. (2020). Asian And African Business Student : A compare Analysis Of Their Motivation, Family Support and Culture On Business Orientation. International Journal Of Economic and Business Administration, 109-123.

Klerk, S. D. (2014). The creative entrepreneur or the entrepreneurial creator. Sydney: Conference: Australian Centre for Entrepreneurship, At Sydney.

Lestari, W. B. (2017). Pemenuhan Kepentingan Gender Melalui Sekolah Perempuan di Desa Kesamben Kulon, Wringinanom Kabupaten Gresik. Jurnal Fis Ant Universitas Airlangga, 117.

Mu'alifah, S. (2019). Daftar Isian Tingkat Perkembangan Desa Dan Kelurahan. Gresik: prodeskel.binapemdes.kemendagri.go.id_terkini_tingkat/pelaporan_terkinitingkat.php/tahun=2019.

Mustakim, M. Z. (2015). Buku 2 Kepemimpinan Desa. Jakarta: Kementrian desa PDTT.

Rahadi, D. R. (2018). Analisis Sektor Usaha Kecil \& Menengah Menjadi Model Kewirausahaan Sosial Berbasis Ekonomi Kreatif. FIRM (Journal Of Management Studies), 16-31.

setiono, D. A. (2018, Oktober Selasa). Gresik Tambah Sekoper. Retrieved Juni Sabtu, 2020, from Berita Jatim.Com:

http://m.beritajatim.com/pendidikan_kesehatan/343069/gresik_tambah_sekoper,_sekola h_perempuan.html

Sudderth, L. K. (2020). The Women's Project: Educating Women in Rural Nicaragua About Gender and Violence. SAGE Journal Volume: 35 issue: 2 May, 246-259.

Sullaida, Nurmala and Chairil Ahyar. (2018). The Development of an Independent Entrepreurship Model Through Creative Economy for Women in Lhokseumawe City. Proceedings of MICoMS (pp. 87-92). United Kingdom: Emerald Publishing Limited.

Sutopo, D. S. (2016). TINDAKAN KOMUNIKATIF DALAM MODEL PEMBERDAYAAN WANITA PADA SEKOLAH PEREMPUAN DESA, KOTA BATU, JAWA TIMU. Malang: Palastren vol 9 No 1.

UN Women. (2020). Economic Empowerment Rural women. USA: UN Women. 